\title{
BIOCHEMICAL STUDIES AND MITOCHONDRIAL DNA FINGERPRINTING OF HONEY BEE IN SAOUDI ARABIA
}

( Received: 26.3. 2008 )

\author{
By \\ S. A. Al-Otaibi, S. M. Abd-्Alla and A. I. Fahmi \\ Biotechnology Department, Faculty of Science, Taif University, Saudia Arabia
}

\begin{abstract}
Honey bee is an important agricultural insect as they pollinate more than 90 crops and providing honey and other commercial products. The study of genetic relationships (diversity) is important for the selection of suitable diverse parents to obtain races with disease resistance and desirable traits. Traditionally, honey bee genetic diversity was based entirely on morphological markers. However, polymerase chain reaction (PCR) -based markers are suitable for an estimation of genetic relationships or diversity in honey bee. Also, protein markers still used as a molecular marker for genetic diversity in honey bee and many other organisms. In addition, mitochondrial DNA (mtDNA) fingerprinting method was efficiently used for studying the genetic diversity but it was not applied with honey bee before.

Eleven stocks of Apis mellifera were used to study the genetic fingerprinting at the molecular and biochemical levels. The results of molecular analysis in mitochondrial DNA (mtDNA) showed that the total number of fragments were 79 with an average number of 7.9 fragments /primer. The polymorphism ranged from $25 \%$ to $100 \%$ with 11 unique bands. On the other hand, the biochemical analysis revealed that the gene or genes which are responsible for protein synthesis are the same in the eleven stocks. These data would lead to a conclusion that the differences between tolerant and sensitive stocks to mites did not affect the protein concentration in the different stocks. Some colonies showed significant excess of amino acid polymorphism so the concentration of amino acid was affected by tolerant and sensitivity to mites in these colonies.

These results led to the possibility of using mtDNA as a reliable and quick method for studying the genetic fingerprints in these stocks, as well as the biochemical levels.
\end{abstract}

Key words: amino acid, apis mellifera, mtdna, protein, RAPD.

\section{INTRODUCTION}

Honey bee is an important agricultural insect pollinating more than 90 crops and providing honey and other commercial products. Although the taxonomic description of honey bees from the African continent dates back to 1804 when the French entomologist Latreille named a bee from Senegal Apis adansonii (Latreille, 1804), the study of honey bees from this continent remained superficial and incomplete until far into this century. For more than 150 years, Apis mellifera adansonii was used as the only name for all the bees of sub- Saharan Africa (Buttel-Reepen, 1906 and Kerr, 1958), although it became known later that substantial geographic variability exists among honey bee populations of this vast region (Ruttner, 1976 and 1988). Analysis of mtDNA variation, proved that samples which were morphometrically identified as A. m. monticola had a unique haplotype, in addition to sharing other haplotypes with A. m. scutellata, thus lending additional support to the 'refugial hypothesis' (Ruttner, 1988). Morphometric analysis of $A$. $m$. litorea suggests that it is a distinct subspecies (Lou et al. 1998), but no molecular data are currently available to better describe its relationship to the neighboring A. $m$. scutellata.

Genomic fingerprints are increasingly used to study the relationships at the intra- or even interspecific level. The fingerprints are obtained by visualizing many parts of the genome. Differences in these fingerprints between individuals are interpreted as genetic distances. Obviously, the differences should reflect variations in DNA rather than artifacts due to a non-robust method. Furthermore, the method should provide the appropriate level of discriminatory power and it should be relatively rapid and cheap, especially in large-scale population genetics studies (Williams et al., 1990 and Chapuisat et al., 1997). 
Up till now the most widely used PCR-based multilocus DNA fingerprint techniques are random amplified polymorphic DNA (RAPD) (Vos et al., 1995) and the more recently proposed amplified fragment length polymorphism (AFLP) (Pejic et al., 1998). RAPD is generally regarded to be less time consuming, while the AFLP method is more robust (Williams et al., 1990 and Mueller and Wolfenbarger 1999).

The mite Varroa jacobsoni, initially an ectoparasite of the bee A. cerana, was first found on A. mellifera in the 1950s. When this mite parasitized A. cerana, it remained limited to the local infested area. However, a rapid man-aided dispersal was observed soon after contact with $A$. mellifera, since the contact between Varroa and A. mellifera, caused serious problems worldwide. The effects of the parasite on honey bees range from weakening to death of parasitized colonies, with the intensity of the problem being directly related to the level of infestation. Climate and $A$. mellifera race were found to be important factors that affect the development of this parasite. However some types of A. mellifera, show resistance to Varroa comparedto bee races. One of the factors that is thought to be involved in this resistance is the fact that the reproductive ability of Varroa females is known to be lower in resistant bees. Some scientist observed that $A$. cerana has a strong defense mechanism against Varroa jacobsoni. When resistance A. cerana workers were artificially infested with varroa females, $99 \%$ succeeded in ridding themselves of the parasite by performing body movements that expelled or removed it from their body. It was also observed that many of the mites that left the host workers were killed by the infested worker itself or its fellow workers. Lowery and Randall (1977) collected mites from the bottom of resistance bee colonies, and they noticed that the occurrence of mutilations in several parts of their body, indicating possible attacks by the workers. The objectives of the present study were to determine the genetic variability in mDNA, proteins and amino acids among eleven stocks of Apis mellifera tolerant and sensitive to mites.

\section{MATERIALS AND METHODS \\ 2.1 Apis mellifera stocks}

Eleven colonies representing three honeybee races namely; Balady ( Apis mellifera yementica) tolerant to mites, Mostord (Apis mellifera carnica) sensitive to mites and Balady hybrids (hybrids between Balady and Mostord) moderately tolerant. These colonies were collected from the gene pool of the Bee Research Unit of King Saud University. The eleven colonies were four Balady, three Mostord and four Balady hybrids. Mostord bees were imported from Egypt whereas the Balady bees were brought from the south of the kingdom (Al Ghamdi, 2002). This research has been conducted in the Biotechnology department, Taif university, Faculty of Science, Kingdom of Saudi Arabia during the years of 2006-2007. The flies were incubated at $25^{\circ} \mathrm{C}$ in the optimal medium (10 gm cornmeal, $10 \mathrm{gm}$ sucrose, $10 \mathrm{gm}$ yeast, $1.5 \mathrm{gm}$ agar-agar and $2 \mathrm{ml}$ propionic acid) / 100 $\mathrm{ml}$ water.

\subsection{Determination of total protein extracts}

The protein content of the different genotypes of A. mellifera was determined according to the method of Cohen et al. (1989).

\subsection{Determination of total amino acid extracts}

The amino acid composition of the experimental samples was determined using HPLC-Pico-Tag method according to Millipore Cooperative procedure (Latorre et al., 1986).

\subsection{Molecular analysis of mtDNA experiments 2.4.1 Extraction of mtDNA}

mtDNA was extracted from the different genotypes of $A$. mellifera using mini preparation (mini prep) method that is performed in much shorter periods according to Latorre et al. (1988) and Nei and Tajima (1981).

\subsubsection{Polymerase chain reaction with random primers for mtDNA}

RAPD-PCR was carried out according to the procedure given by Vos et al. (1995). Ten random primers (10-mer) were purchased from Operon kit A (Operon technologies, Inc., Alamada, CA, USA) and screened for its ability to polymorphisms. The primer sequences were as follows:

$\begin{array}{cc}\text { Primer } & \text { 5' } \text { Sequence 3' } \\ \text { OPA04 } & \text { 5'-AACGGGCTG -3' } \\ \text { OPA05 } & \text { 5'-AGGGGTCTTG-3' } \\ \text { OPA09 } & \text { 5'-GGGTAACGCC-3' } \\ \text { OPA11 } & \text { 5'-CAATCGCCGT-3' } \\ \text { OPA14 } & \text { 5'-TCTGTGCTGG-3' } \\ \text { OPA15 } & \text { 5'-TTCCGAACCC-3' } \\ \text { OPA16 } & \text { 5'-AGCCAGCGAA-3' } \\ \text { OPA17 } & \text { 5'-GACCGCTTGT-3' } \\ \text { OPA19 } & \text { 5'-CAAACGTCGG-3' } \\ \text { OPA20 } & \text { 5'-GTTGCGATCC-3' }\end{array}$

PCR reaction was carried out in a volume of $50 \mu 1$ containing $1 \mu \mathrm{l}$ of $50 \mathrm{ng} / \mu \mathrm{l}$ template DNA, $4 \mu \mathrm{l}$ of $10 \mu \mathrm{M}$ decamer oligonucleotide primer from, 0.5 $\mu \mathrm{l}$ of $5 \mathrm{u} / \mu \mathrm{l}$ of Taq. DNA polymerase (Finepoll), $5 \mu \mathrm{l}$ of 10x buffer ( $500 \mathrm{mM} \mathrm{Kcl}, 100 \mathrm{mM}$ Tris$\mathrm{Hcl} \mathrm{pH} 9.0$ and $1 \%$ Triton $\mathrm{x}-100), 2 \mu 1$ of $50 \mathrm{mM}$ 
$\mathrm{Mgcl}_{2}, 5 \mu \mathrm{l}$ of $2 \mathrm{mM}$ dNTPs (dATP, dCTP, dTTP, dGTP) and deionized dd $\mathrm{H}_{2} \mathrm{O}$.

PCR amplification was performed in a thermal cycle programme for one cycle of $3 \mathrm{~min}$. at $94^{\circ} \mathrm{C}, 40$ cycles of $1 \mathrm{~min}$ at $948^{\circ} \mathrm{C}, 1 \mathrm{~min}$ at 36 $\dot{\circ}^{\circ} \mathrm{C}$, and $2 \mathrm{~min}$ at $72 \circ^{\circ} \mathrm{C}$, and a final cycle of 5 $\min$ at $72^{\circ} \mathrm{C}$.

\subsubsection{Electrophoresis of PCR products}

The amplification products were resolved by electrophoresis in a $1.5 \%$ agarose gel (Sigma) containing $0.5 \mu \mathrm{g} / \mathrm{ml}$ ethidium bromide in $1 \mathrm{x}$ TAE buffer. After electrophoresis, the RAPD patterns of the PCR products were visualized under UV light.

\subsection{Statistical analysis}

The test of $\left(\chi^{2}\right)$ and $(2 \times 2)$ analysis were used aiming to clarify the significant and nonsignificant patterns of RAPD analysis and total protein in different stocks of $A$. mellifera used in the study according to Moretto and Joao de Mello (1999).

\section{RESULTS AND DISCUSSION}

To shed some light on the different genotypes of A. mellifera which have been used in this study, the present data may reveal some aspects for comparing eleven stocks. The criteria of these comparisons include differences in tolerance and sensitivity to mites, the variability in mtDNA, also in the total protein content and total amino acids in all of these stocks.

\subsection{Determination of total proteins}

Table (1) shows no variability in the total protein content between them, however the total protein concentrations for all eleven stocks of $A$. mellifera was measured and the data presented in Table (1) ranging between $16 \%$ to $22.76 \%$ with an average of $19.19 \%$. The statistical analysis $\left(\chi^{2}\right)$ and comparing each strain with the other on the

Table (1) : Total protein concentrations in the eleven stocks of Apis mellifera as determined according to the method of Lowery and Randall (1977).

\begin{tabular}{|l|c|c|}
\hline \multicolumn{1}{|c|}{ Stocks } & $\begin{array}{c}\text { Protein } \\
\text { conc. \% }\end{array}$ & $\begin{array}{c}\text { Calculated } \\
\left(\boldsymbol{\chi}^{\mathbf{2}}\right) \text { values }\end{array}$ \\
\hline Balady 3 & 19.21 & \\
\hline Balady 5 & 20.14 & 0.0219 \\
\hline Balady 6 & 20.96 & 0.076 \\
\hline Balady 7 & 16.94 & 0.1425 \\
\hline Balady 8 hybrid & 22.76 & 0.0023 \\
\hline Balady 9 hybrid & 19.87 & 0.1892 \\
\hline Balady 10 hybrid & 19.11 & 0.3181 \\
\hline Balady 11 hybrid & 16.00 & 1.1789 \\
\hline Mostord 12 & 18.37 & 0.0962 \\
\hline Mostord 13 & 20.23 & 0.0010 \\
\hline Mostord 14 & 17.45 & 0.1294 \\
\hline
\end{tabular}

protein level encourage us to suggest that the total protein concentrations among the stocks could not detect variations among these eleven stocks. In other words there are no significant variations in the concentration of these proteins. These results demonstrated that the gene or genes which are responsible for protein synthesis are the same in the experimental strains. These data would lead to a conclusion that the protein concentration had no influence in tolerant and sensitive stocks in response to mites.

\subsection{Determination of total amino acids}

The data obtained from the present work show some characteristics for total amino acid and protein concentrations of the eleven stocks of $A$. mellifera in case of using HPLC-Pico-Tag method according to Millipore. The concentrations of the total amino acids of the eleven stocks of $A$. mellifera are shown in (Table 2). From the presented values, the highest amino acid ratio in the first strain is for arginine and estimated with $4.739 \%$, while the lowest amino acid ratio is for four amino acids and estimated with $0.00 \%$. By a comparison, it was also found that the highest amino acid ratio is for aspartic and ranged this was tree between $0.556 \%$ and $7.334 \%$. with serine and ranged from 1.543 and 6.891. Also, it was observed that the amino acid therionine in all the stocks was absent and estimated with $0.00 \%$. Moreover, the lowest amino acid ratio in all the stocks was, for methionine ranging between $0.004 \%$ and $0.119 \%$. .

On the other hand, the essential amino acid aspartic increased in the fifth strain and estimated with $7.33 \%$, while it was decreased in all experimental strains and ranging between $0.557 \%$ and $5.428 \%$. Also, serine was increased in sixth strain and estimated with $6.891 \%$, while it was decreased in all the experimental strains and ranging between $4.898 \%$ and $1.543 \%$. The concentrations of the total amino acids in the tolerant stocks ranged from $0.00 \%$ and $4.739 \%$, in case of sensitive stocks total amino acids ranged from $0.00 \%$ and $5.428 \%$. While in the hybrid stocks, the total amino acids ranged from $0.00 \%$ and $7.334 \%$. From these data, some stocks showed significant excess of amino acid polymorphism within and between them. Rand et al. (1994) found that the significant excess of amino acid polymorphism within both Drosophila melanogaster and Drosophila simulans species is localized in one region of the protein. They added that mtDNA evolution has been faster in $D$. melanogaster than in D. simulans and the population structure of mtDNA is distinct in these species. A comparison within and between $D$. melanogaster, D. simulans, and D. yakuba species concerning the ratio of amino acid replacement 
change to synonymous change that reveals a relative excess of amino acids replacement polymorphism compared to the neutral prediction of William et al. (1994). Rand and Kann (1996) stated that both Drosophila and human mtDNA show very significant excess of amino acid polymorphism. A pattern of excess amino acid polymorphism holds across the entire mitochondrial genome when $D$. melanogaster and D. simulans were compared (Rand, 2001). Also the representation of cysteine appears to correlate positively with the complexity of the organism. Miseta and Csutora (2000) investigated the occurrence of cysteine in known proteins of various species. Cysteine is a relatively rare amino acid within the proteins of investigated organisms and protein of the fruit fly contained somewhat less cysteine $(1.90 \%)$.

\subsection{Isolation of mtDNA}

The insect mitochondrial genomes are closed circular and have the universal genetic code. The genome size varies from 14,422 bp (in $M$. bicolor) to $19,517 \mathrm{bp}$ (D. melanogaster). All insect mtDNA are similar in size except for $D$. melanogaster mtDNA which is larger compared to other species of Drosophila due to the presence of a noncoding 4553-bp region at the end of genome and it has 14 coding genes compared to 13 in most insects (Chandra et al., 2006). Mitochondrial DNA (mt.DNA) size among the $D$. melanogaster species subgroup varies from 16.0 to $19.0 \mathrm{~kb}$. However, the mtDNA size among the D. melanogaster species subgroup varies from 16.0 to $19.0 \mathrm{~kb}$. However, the mtDNA size variation within the $D$. melanogaster species complex ranges from 18.0 to $19.0 \mathrm{~kb}$. Shah and Langley (1979) estimated the size of mtDNA in D. melanogaster to be $18.6 \mathrm{kbp}$. In comprehensive studies, Hale and Singh (1986 and 1991) recorded many cases of mtDNA size variations in D. melanogaster. They classified the mtDNA size to 14 different size classes began with $18.2 \mathrm{kbp}$ until $19.9 \mathrm{kbp}$, with predominant of $18.6 \mathrm{kbp}$ class size. Choi and Choo (1993) estimated mtDNA size to be $18.9 \mathrm{kbp}$ in $D$. melanogaster. This size variation may be due to cases of insertion or deletion and to the presence of transposable genetic elements.

\subsubsection{RAPD-PCR in mtDNA of eleven stocks of $A$.} mellifera

mtDNA has been the most widely studied region of eukaryotic genomes and has played a critical role in the development of population and evolutionary genetics (Rand et al., 1994). Rand (2001) demonstrated that mtDNA was a neutral genetic marker. Also the analyses of Drosophila mitochondrial genomes, especially those on $D$. melanogaster were among the first ones devoted to animal organisms (Polan et al., 1973). While in honey bee mtDNA variations were detected in many subspecies (Eixner et al., 2000; Sheppard et al. 96, 1999).

Mitochondrial DNA (mt.DNA) variation is an important tool in the analysis of phylogenies of honey bee (Canovas et al., 2008).

Mt.DNA is an important tool in the analysis of phylogenies of closely related species in population structures of individual species (Latorre et al., 1988). mtDNA is appropriate because of its uniparental inheritance, non recombinogenicity, small size, and elevated rate of mutation (reviewed in Hale and Singh, 1991).

The use of RAPD-PCR is aiming to show fast and reliable discrimination of any variations. The purified mtDNA of the eleven different stocks was produced when they are used as templates for RAPD-PCR, characteristic reproducible multipleband profiles of amplified fragments. Out of 22 tested primers, only ten succeeded in this test. The results of RAPD-PCR analysis in mtDNA using primer (OPA04) are illustrated in Fig. (1) and Table (3). The molecular size of the 9 PCR products ranged from $250 \mathrm{bp}$ to $1500 \mathrm{bp}$. Two common bands of $450 \mathrm{bp}$, and $400 \mathrm{bp}$ were observed in the eleven stocks of $A$. mellifera species and exhibited $22.2 \%$ monomorphism, while the seven remaining bands were polymorphic with percentage $77.8 \%$.

Four bands in the eleven strain of A. mellifera species with primer (OPA05) are illustrated in Fig. (1) and Table (4) at a molecular size ranging between $190 \mathrm{bp}$ to $400 \mathrm{bp}$. There were three common bands with molecular size of $190 \mathrm{bp}$, $200 \mathrm{bp}$ and $300 \mathrm{bp}$ present in all species which exhibited $75 \%$ monomorphism. The remainder one band was polymorphic with percentage $25 \%$.

The results of RAPD-PCR with primer (OPA09) are shown in Fig. (1) and Table (5). The molecular size of these products ranged from 250 $\mathrm{bp}$ to $900 \mathrm{bp}$. This primer gave 6 polymorphic bands with percentage $100 \%$.

The RAPD-PCR products of primer (OPA11) are illustrated in Fig. (1) and Table (6). It is obvious that the total number of bands is 8 with molecular size ranging from $250 \mathrm{bp}$ to $1100 \mathrm{bp}$.

The results also indicated that there was one common band with molecular sizes of $450 \mathrm{bp}$, while all the remaining bands were polymorphic. The polymorphic bands exhibited $87.5 \%$ with one positive unique band with molecular sizes of 450 bp in stock number 8 .

The results of RAPD-PCR analysis using primer ( OPA 14 ) are depicted in Fig. (1) and 
Table (2): Total amino acid concentrations (\%).

\begin{tabular}{|l|c|c|c|c|c|c|c|c|c|c|c|}
\hline \multirow{2}{*}{ Amino acids } & \multicolumn{9}{|c|}{ Stocks } \\
\cline { 2 - 12 } & $\mathbf{1}$ & $\mathbf{2}$ & $\mathbf{3}$ & $\mathbf{4}$ & $\mathbf{5}$ & $\mathbf{6}$ & $\mathbf{7}$ & $\mathbf{8}$ & $\mathbf{9}$ & $\mathbf{1 0}$ & $\mathbf{1 1}$ \\
\hline Aspartic & 3.039 & 2.031 & 1.731 & 0.557 & 7.334 & 4.608 & 2.530 & 2.064 & 5.428 & 1.305 & 0.599 \\
\hline Glutamic & 2.462 & 3.960 & 3.413 & 5.055 & 2.717 & 3.716 & 2.377 & 4.557 & 2.731 & 3.599 & 2.008 \\
\hline Serine & 2.938 & 2.759 & 3.389 & 1.816 & 4.898 & 6.891 & 2.985 & 1.798 & 1.543 & 1.891 & 1.830 \\
\hline Glycine & 1.927 & 0.771 & 0.210 & 0.374 & 0.000 & 0.000 & 1.061 & 0.235 & 0.000 & 0.187 & 0.842 \\
\hline Histedine & 1.830 & 1.057 & 2.586 & 0.999 & 1.797 & 0.000 & 0.000 & 0.967 & 0.860 & 1.332 & 1.975 \\
\hline Arginine & 4.739 & 0.369 & 0.685 & 0.000 & 0.000 & 0.287 & 2.901 & 0.000 & 0.860 & 1.781 & 0.000 \\
\hline Therionine & 0.000 & 0.000 & 0.000 & 0.000 & 0.000 & 0.000 & 0.000 & 0.000 & 0.000 & 0.000 & 0.000 \\
\hline Alanine & 0.000 & 3.084 & 2.043 & 2.157 & 2.140 & 1.481 & 4.882 & 2.423 & 1.525 & 2.583 & 1.970 \\
\hline Proline & 0.000 & 0.326 & 0.328 & 0.307 & 0.373 & 0.147 & 0.423 & 0.252 & 0.168 & 0.141 & 0.163 \\
\hline Tyrosine & 0.257 & 2.060 & 0.672 & 1.355 & 1.427 & 1.269 & 0.252 & 1.455 & 0.887 & 0.851 & 0.655 \\
\hline Valine & 0.345 & 0.006 & 0.875 & 1.326 & 0.481 & 0.525 & 0.219 & 0.544 & 1.046 & 1.685 & 1.769 \\
\hline Methionine & 0.000 & 0.011 & 0.004 & 0.201 & 0.000 & 0.000 & 0.089 & 0.004 & 0.102 & 0.119 & 0.102 \\
\hline Cystine & 0.007 & 1.519 & 0.202 & 0.000 & 0.225 & 0.212 & 0.162 & 0.646 & 0.000 & 0.000 & 0.000 \\
\hline Isoleucine & 1.568 & 0.476 & 3.356 & 0.000 & 0.000 & 0.000 & 0.595 & 0.521 & 3.215 & 4.392 & 5.223 \\
\hline Leucine & 0.006 & 0.491 & 0.685 & 2.787 & 1.242 & 0.727 & 0.368 & 0.488 & 0.000 & 0.000 & 0.000 \\
\hline Phenylalanine & 0.049 & 1.189 & 0.733 & 0.000 & 0.000 & 0.000 & 0.115 & 0.025 & 0.000 & 0.000 & 0.000 \\
\hline Lysine & 0.032 & 0.020 & 0.040 & 0.000 & 0.118 & 0.000 & 0.144 & 0.013 & 0.000 & 0.357 & 0.308 \\
\hline
\end{tabular}



Table (3): Scoring of RAPD-PCR markers for the eleven stocks of mtDNA generated by RAPD-PCR in case of using primer OPA 04.

\begin{tabular}{|c|c|c|c|c|c|c|c|c|c|c|c|c|}
\hline & \multicolumn{11}{|c|}{ Different genotypes of Apis mellifera } & \multirow{2}{*}{$\begin{array}{c}\text { Molecular } \\
\text { weights (bp) }\end{array}$} \\
\hline \multirow{10}{*}{ 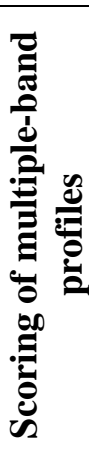 } & 1 & 2 & 3 & 4 & 5 & 6 & 7 & 8 & 9 & 10 & 11 & \\
\hline & + & - & - & - & + & + & - & - & - & - & - & 1500 \\
\hline & + & + & + & - & + & + & + & + & - & - & - & 900 \\
\hline & + & + & - & - & - & - & + & + & - & + & + & 800 \\
\hline & - & - & + & - & + & + & + & + & - & + & + & 700 \\
\hline & + & + & - & - & - & - & + & + & - & - & - & 600 \\
\hline & + & + & + & - & + & + & + & + & - & + & + & 500 \\
\hline & + & + & + & + & + & + & + & + & + & + & + & 450 \\
\hline & + & + & + & + & + & + & + & + & + & + & + & 400 \\
\hline & + & - & - & - & - & - & - & + & - & - & - & 250 \\
\hline
\end{tabular}

Table (4): Scoring of RAPD-PCR markers for the eleven stocks of mtDNA using primer OPA 05.

\begin{tabular}{|c|c|c|c|c|c|c|c|c|c|c|c|c|}
\hline & \multicolumn{11}{|c|}{ Different genotypes of Apis mellifera } & \multirow{2}{*}{$\begin{array}{c}\text { Molecular } \\
\text { weights } \\
\text { (bp) }\end{array}$} \\
\hline \multirow{5}{*}{ 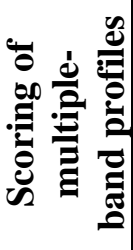 } & 1 & 2 & 3 & 4 & 5 & 6 & 7 & 8 & 9 & 10 & 11 & \\
\hline & - & - & - & - & + & + & + & - & - & - & - & 400 \\
\hline & + & + & + & + & + & + & + & + & + & + & + & 300 \\
\hline & + & + & + & + & + & + & + & + & + & + & + & 200 \\
\hline & + & + & + & + & + & + & + & + & + & + & + & 190 \\
\hline
\end{tabular}

Table (5): Summary of RAPD-PCR markers used to identify eleven stocks of mtDNA in case of using primer OPA 09.

\begin{tabular}{|c|c|c|c|c|c|c|c|c|c|c|c|c|}
\hline & \multicolumn{11}{|c|}{ Different genotypes of Apis mellifera } & \multirow{2}{*}{$\begin{array}{r}\text { Molecular } \\
\text { weights (bp }\end{array}$} \\
\hline \multirow{7}{*}{ 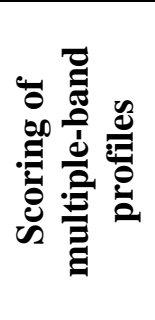 } & 1 & 2 & 3 & 4 & 5 & 6 & 7 & 8 & 9 & 10 & 11 & \\
\hline & + & - & - & - & - & + & - & - & - & - & - & 900 \\
\hline & + & - & - & - & - & - & - & - & - & - & - & 700 \\
\hline & - & + & + & + & + & + & - & + & - & + & + & 600 \\
\hline & - & + & + & + & + & - & + & + & - & + & + & 500 \\
\hline & + & + & + & + & + & + & - & - & - & + & + & 300 \\
\hline & - & + & + & + & + & - & - & + & + & + & + & 250 \\
\hline
\end{tabular}

Table (6): Scoring of RAPD-PCR markers for the eleven stocks of mtDNA using primer OPA 11.

\begin{tabular}{|c|c|c|c|c|c|c|c|c|c|c|c|c|}
\hline & \multicolumn{11}{|c|}{ Different genotypes of Apis mellifera } & \multirow{2}{*}{$\begin{array}{l}\text { Molecular } \\
\text { weights (bp) }\end{array}$} \\
\hline \multirow{9}{*}{ 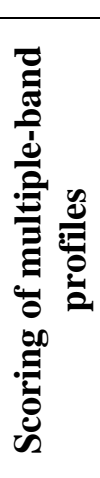 } & 1 & 2 & 3 & 4 & 5 & 6 & 7 & 8 & 9 & 10 & 11 & \\
\hline & + & + & + & - & + & + & + & + & - & - & - & 1100 \\
\hline & + & + & + & - & + & + & + & + & - & - & + & 1000 \\
\hline & - & - & - & - & + & + & - & - & - & - & + & 900 \\
\hline & + & - & - & - & - & + & + & + & - & + & + & 700 \\
\hline & + & - & - & - & - & - & - & + & - & - & - & 600 \\
\hline & + & + & + & + & + & + & + & + & + & + & + & 450 \\
\hline & - & - & - & - & - & - & - & + & - & - & - & 300 \\
\hline & + & - & - & - & - & - & - & - & - & + & + & 250 \\
\hline
\end{tabular}


Table (7): Diagnostic bands of eleven stocks of mtDNA generated by RAPD-PCR in the case of using primer OPA 14

\begin{tabular}{|c|c|c|c|c|c|c|c|c|c|c|c|c|}
\hline & \multicolumn{11}{|c|}{ Different genotypes of Apis mellifera } & \multirow{2}{*}{$\begin{array}{l}\text { Molecular } \\
\text { weights (bp) }\end{array}$} \\
\hline \multirow{7}{*}{ 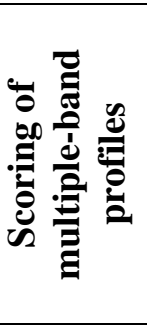 } & 1 & 2 & 3 & 4 & 5 & 6 & 7 & 8 & 9 & 10 & 11 & \\
\hline & - & + & - & - & - & - & + & - & - & - & - & 800 \\
\hline & - & - & - & + & + & + & + & - & + & + & + & 700 \\
\hline & + & - & - & - & - & - & - & + & - & - & - & 500 \\
\hline & + & + & + & + & + & + & + & + & - & - & - & 450 \\
\hline & - & - & - & - & + & + & + & - & - & - & - & 300 \\
\hline & - & - & + & + & + & + & - & - & + & + & + & 250 \\
\hline
\end{tabular}

Table (7). The results reveal that this primer produced 6 bands with molecular sizes ranging from $250 \mathrm{bp}$ to $800 \mathrm{bp}$. In the eleven stocks, the six bands were polymorphic with percentage $100 \%$. there was one band with a molecular size of 500 bp present in stocks number 1 . This band might be considered as specific positive marker.

Ten bands with primer (OPA16) are illustrated in Fig.(1) and Table (9) with molecular

Table (8): Scoring of RAPD-PCR markers for the eleven stocks of mtDNA using primer OPA 15

\begin{tabular}{|c|c|c|c|c|c|c|c|c|c|c|c|c|}
\hline & \multicolumn{10}{|c|}{ Different genotypes of Apis mellifera } & \multicolumn{1}{c|}{ Molecular } \\
weights (bp)
\end{tabular}

Table (9): Summary of RAPD markers used to identify eleven stocks of mtDNA in the case of using primer OPA 16.

\begin{tabular}{|c|c|c|c|c|c|c|c|c|c|c|c|c|}
\hline & \multicolumn{10}{|c|}{ Different genotypes of Apis mellifera } & \multicolumn{1}{c|}{ Molecular } \\
weights (bp)
\end{tabular}

Fig. (1) and Table (8) show the results of RAPD-PCR with primer (OPA15) and illustrated that the molecular size of the PCR products ranged from $100 \mathrm{bp}$ to $900 \mathrm{bp}$. It gave 6 polymorphic bands with different molecular sizes which exhibited $60 \%$ and four monomorphic bands which exhibited $40 \%$. On the other hand, size ranging between $270 \mathrm{bp}$ to $1500 \mathrm{bp}$. The remainder 10 bands were polymorphic with percentage $100 \%$.

RAPD-PCR products with primer (OPA17) are illustrated in Fig. (1) and Table (10). This primer gave 9 polymorphic bands with different molecular sizes ranging between 200 bp to 1000 
Table (10): Scoring of RAPD-PCR markers for the eleven stocks of mtDNA using primer A 17.

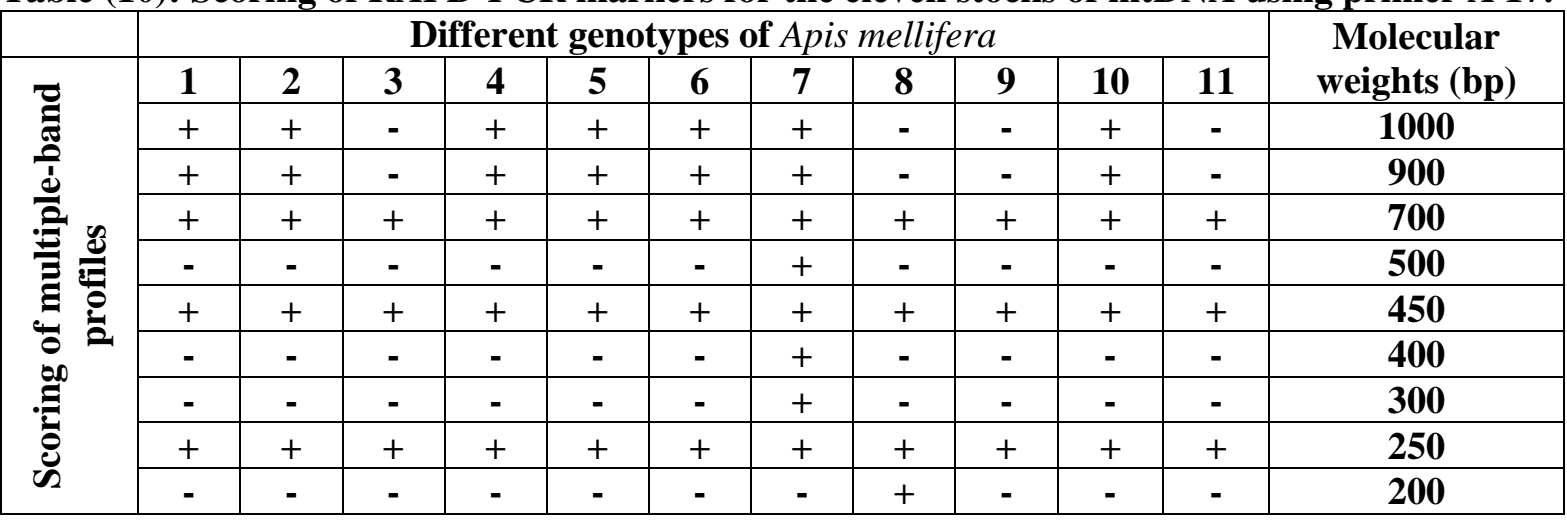

bp and four unique bands at molecular sizes of $500 \mathrm{bp}, 400 \mathrm{bp}, 300 \mathrm{bp}$ and $200 \mathrm{bp}$ which could be used as positive molecular marker for stock number 7 and 8 . These polymorphic bands exhibited $66.7 \%$. Three common bands of $700 \mathrm{bp}$, $450 \mathrm{bp}$, and $250 \mathrm{bp}$ were observed in the eleven stocks. present in the eleven stocks, while the other bands were polymorphic with percentage $75 \%$. However, three bands with molecular size of 700 bp and, $150 \mathrm{bp}$ were detected only in stock number 6 and 9 and could be used as a positive marker for these stocks; while one band sized 250 bp could be used as a negative marker.

Table (11): Summary of RAPD markers used to identify eleven stocks of mtDNA in the case of using primer OPA 19.

\begin{tabular}{|c|c|c|c|c|c|c|c|c|c|c|c|c|}
\hline & \multicolumn{11}{|c|}{ Different genotypes of Apis mellifera } & \multirow{2}{*}{$\begin{array}{c}\text { Molecular } \\
\text { weights (bp) }\end{array}$} \\
\hline \multirow{9}{*}{ 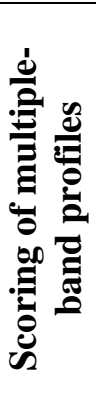 } & 1 & 2 & 3 & 4 & 5 & 6 & 7 & 8 & 9 & 10 & 11 & \\
\hline & - & - & - & - & - & + & - & - & - & - & - & 700 \\
\hline & + & + & + & - & - & - & - & - & - & - & - & 600 \\
\hline & + & - & - & - & - & + & - & - & - & - & - & 550 \\
\hline & + & + & + & + & + & + & + & + & + & + & + & 500 \\
\hline & - & - & - & + & + & + & - & - & + & - & - & 400 \\
\hline & + & + & + & + & + & + & + & + & + & + & + & 300 \\
\hline & - & + & + & + & + & + & + & + & + & + & + & 250 \\
\hline & - & - & - & - & - & - & - & - & + & - & - & 150 \\
\hline
\end{tabular}

Table (12): Scoring of RAPD-PCR markers for the eleven stocks of mDNA using primer OPA 20.

\begin{tabular}{|c|c|c|c|c|c|c|c|c|c|c|c|c|}
\hline & \multicolumn{11}{|c|}{ Different genotypes of Apis mellifera } & \multirow{2}{*}{$\begin{array}{c}\text { Molecular } \\
\text { weights (bp) }\end{array}$} \\
\hline \multirow{10}{*}{ 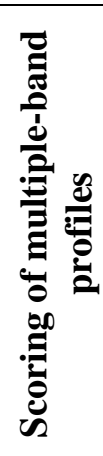 } & 1 & 2 & 3 & 4 & 5 & 6 & 7 & 8 & 9 & 10 & 11 & \\
\hline & - & - & - & + & + & - & - & - & - & - & - & 2000 \\
\hline & + & + & + & + & + & + & + & - & - & - & - & 1500 \\
\hline & - & + & + & + & + & + & + & - & - & - & - & 1400 \\
\hline & - & + & - & - & - & + & + & - & - & + & - & 900 \\
\hline & + & + & + & + & + & + & + & + & + & + & + & 800 \\
\hline & - & + & - & + & - & + & + & + & + & + & + & 500 \\
\hline & + & + & + & + & + & + & + & + & + & + & + & 400 \\
\hline & - & - & - & - & - & - & - & + & - & - & - & 350 \\
\hline & - & - & - & - & - & - & - & + & - & - & - & 300 \\
\hline
\end{tabular}

The results of RAPD-PCR analysis using primer (OPA19) are depicted in Fig. (1) and Table (11). The results revealed that this primer produced 8 bands with molecular sizes ranging between $150 \mathrm{bp}$ and $700 \mathrm{bp}$. Two common bands with molecular size of $300 \mathrm{bp}$ and $500 \mathrm{bp}$ were
The results of primer (OPA20) are shown in Fig. (1) and Table (12). This primer produced 9 bands with molecular size ranging between $100 \mathrm{bp}$ to $1875 \mathrm{bp}$. There were three polymorphic bands which exhibited $33.33 \%$ and six common bands with molecular sizes of $930 \mathrm{bp}, 910 \mathrm{bp}, 360 \mathrm{bp}$, 
A

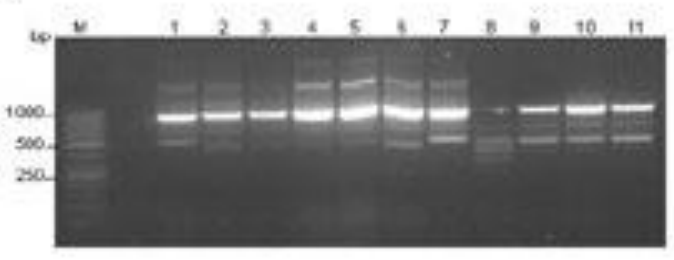

B

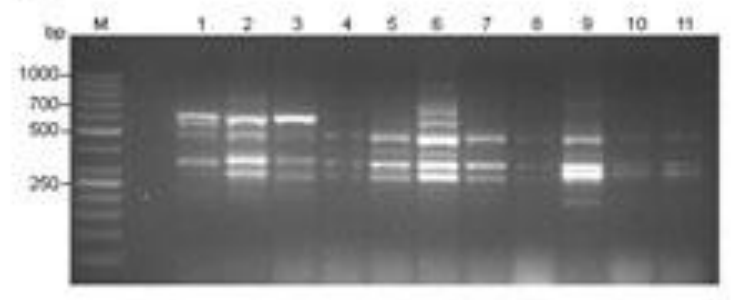

C

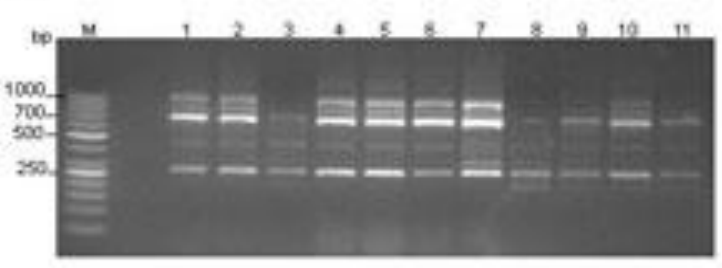

D

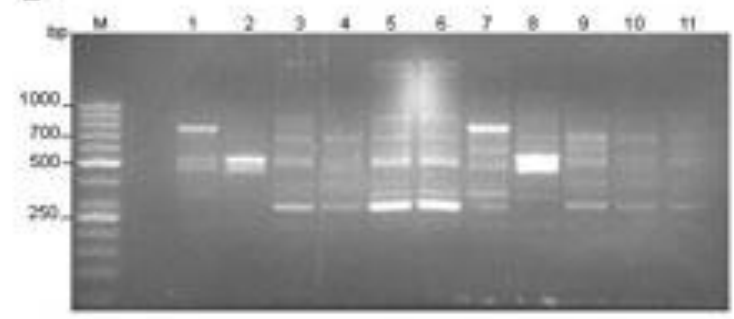

E

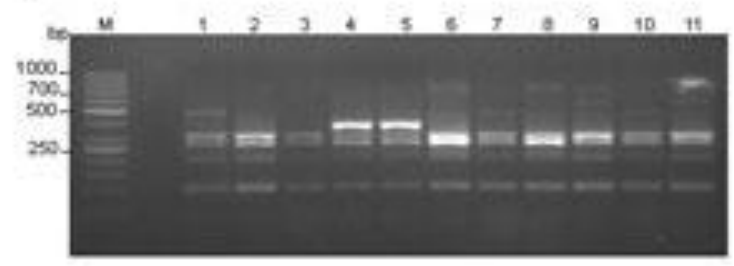

F

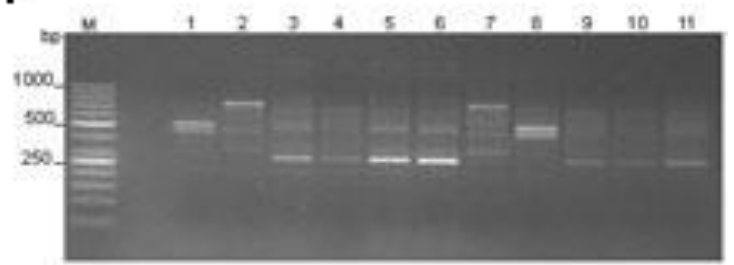

G

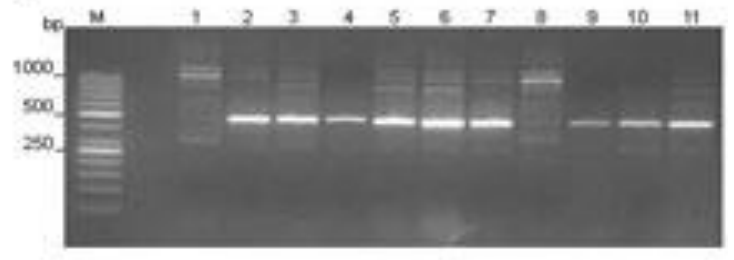

H

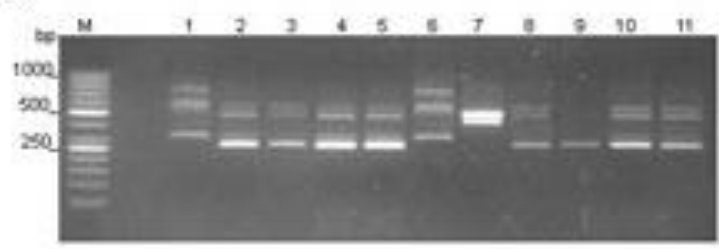

I

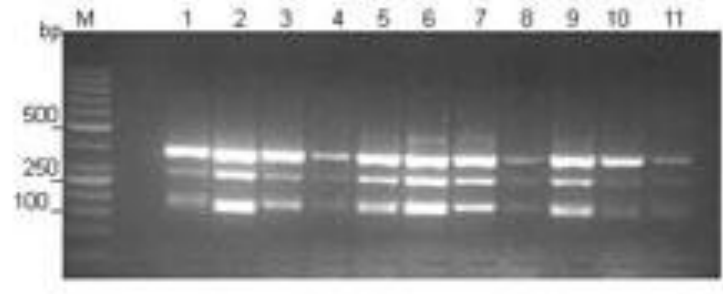

J

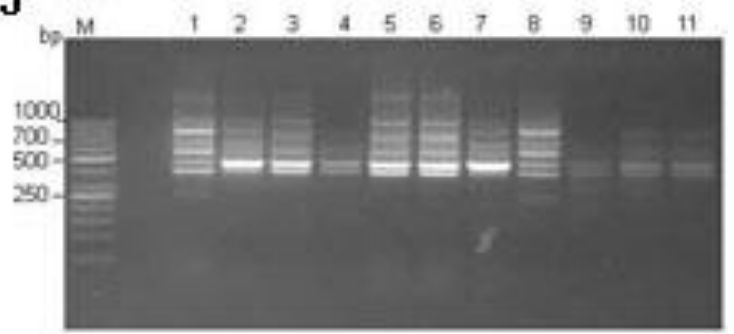

Fig.(1): RAPDs amplification of mtDNA of Apis mellifera.M,molecular marker -50 bp DNA ladder, (1) Baldy 3, (2) Baldy 5, (3) Baldy 6, (4) Baldy 7, (5) Baldy 8 hybrid, (6) Baldy 9 hybrid, (7) Baldy 10 hybrid, (8) Baldy 11 hybrid, (9) Mostord 12, (10) Mostord 13, (11) Mostord 14. Primers: (A) OPA 20, (B) OPA 19, (C) OPA 17, (D) OPA 16, (E) OPA 15, (F) OPA 14, (G) OPA 11, (H) OPA 09, (I) OPA 05, (J) OPA 04. 
Table (13): Summary of electrophoretic separation pattern of RAPD-PCR products using the ten primers.

\begin{tabular}{|c|c|c|c|c|c|c|}
\hline \multirow{2}{*}{ Primer } & \multicolumn{2}{|c|}{ Polymorphic bands } & \multicolumn{2}{|c|}{ Monomorphic bands } & \multirow{2}{*}{ Unique bands } & \multirow{2}{*}{ Total bands } \\
\hline & No. & $\%$ & No. & $\%$ & & \\
\hline OPA04 & 7 & $\begin{array}{ll}77.8 \\
\end{array}$ & 2 & 22.2 & No & 9 \\
\hline OPA05 & 1 & 25 & 3 & 75 & No & 4 \\
\hline OPA09 & 6 & 100 & No & $\mathbf{0}$ & + & 6 \\
\hline OPA11 & 7 & 87.5 & 1 & 12.5 & + & 8 \\
\hline OPA14 & 6 & 100 & No & $\mathbf{0}$ & No & 6 \\
\hline OPA15 & 6 & 60 & 4 & 40 & + & 10 \\
\hline OPA16 & 10 & 100 & No & 0 & No & 10 \\
\hline OPA17 & 6 & 66.7 & 3 & 33.3 &,,,++++ & 9 \\
\hline OPA19 & 6 & 75 & 2 & 25 &,,++- & 8 \\
\hline OPA20 & 7 & $\mathbf{7 7 . 8}$ & 2 & 22.2 &,++ & 9 \\
\hline Total & 62 & 78.5 & 17 & 21.5 & 11 & 79 \\
\hline Average & 6.2 & & 1.7 & & & 7.9 \\
\hline
\end{tabular}

$300 \mathrm{bp}, 260 \mathrm{bp}$, and $210 \mathrm{bp}$.

\section{Conclusions}

Ten primers were screened with the mtDNA of the 11 A. mellifera genotypes. These primers generated reproducible and easily scorable RAPD profiles. These produced multiple band profiles with a number of amplified mtDNA fragments ranging from 6 to 10 (Table 13). The total number of fragments produced by the ten primers was 79 with an average number of 7.9 fragments / primer. While the number of polymorphic fragments ranged from 1 to 10 . A maximum number of 10 amplicons were amplified with primer OPA15 and OPA16, while the minimum number of 4 fragments was amplified with primer OPA05. The highest number of polymorphic bands (10) was obtained with primer OPA16 that exhibited $100 \%$ polymorphism. The average number of polymorphic fragments / primer among the $11 \mathrm{~A}$. mellifera genotypes was 6.2.

\section{Acknowledgements}

This research was supported by Taif University Grant number 1-428-54.

\section{REFERENCES}

AlGhamdi A. A. (2002). The comprehensive study of the mite Verroa destructor on honeybees Apis melliefra indigenous and imported. Final report, King Abdulaziz City for Science and Technology, MS-4-29.

Buttel-Reepen H. von (1906). Apistica. Beiträge zur Systematik, Biologie, sowie zur geschichtlichen und geographischen Verbreitung der Honigbiene (Apis mellifera L.), ihrer Varietäten und der übrigen ApisArten, Veröff. Zool. Mus. Berlin: 118-120.

Canovas F., De La Rua, P., Serrano, J. and Galian G. (2008). Geographical patterns of
Mitochondrial DNA variation in Apis mellifera iberiensis (Hymenoptra: Apide). Journal of Zoological Systematic and Evolutionary Research 46: 24-30.

Chandra S.B.C., Vlk, J.L. and Kapatral,, V. (2006). Comparative insect mitochondrial genomes: Differences despite conserved genome synteny. African Journal of Biotechnology 5: 1308-1318.

Chapuisat M., Goudet J. and Keller L. (1997). Microsatellites reveal high population viscosity and limited dispersal in the ant Formica paralugubris. Evolution, 51: 475482.

Choi J.K. and Choo J.K. (1993). Restriction site polymorphism and variation in length of the mtDNA of Drosophila melanogaster, D. simulans and D. viriis. Koreanj. Entomol. 23 (3): 151-157.

Cohen S.A., Mewyes M. and Travin T.L. (1989). The Pico-Tag Method. In "A Manual of Advanced Techniques for Amino Acid Analysis", Millipore, USA.

Eixner, M.D., Rias, M.C. and Heppard, W.S. (2000) Mitochondrial DNA polymorphisms in honey bee subspecies from Kenya. Apidologie 31: 181-190.

Hale L.R. and Singh R.S. (1986). Extensive variation and heteroplasmy in size of mtDNA among geographic populations of Drosophila melanogaster. Proc. Natl. Acad. Sci. USA 83: 8813-8817.

Hale L.R. and Singh R.S. (1991). A comprehensive study of genic variation in natural populations' of Drosophila melanogaster. IV. Mitochondrial DNA variation and the role of history vs. selection in the genetic structure of 
geographic populations, Genetics, 129: 103117.

Kerr W.E. (1958). Portugal-Araujo V., Raças de abelhas de Africa, Garcia de Orta 8: 53-59.

Latorre A., Barrio E., Moya A. and Ayala F.J. (1988). Mitochondrial DNA evolution in the Drosophila obscura group. Mol. Biol. Evol. 5: 717-728.

Latorre A., Moya A and Ayala F.J. (1986). Evolution of mitochondrial DNA in Drosophila subobscura. Proc. Natl. Acad. Sci. USA, 83: 8649-8653.

Latreille P.A. (1804). Notice des espèces d'abeilles vivant en grande société et formant des cellules hexagonales, ou des abeilles proprement dites, Ann. Mus. Hist. Nat. Paris 5: 161-178.

Lou K.F., Weiss M.J., Bruckner P.L., Morrill W.L., Talbert L.E. and Martin J.M. (1998) .RAPD variation within and among geographic populations of wheat stem sawfly (Cephus cinctus Norton). J. Hered., 89: 329-335.

Lowery R.F. and Randall A. (1977). A simplification of the protein assay method. Ann. Biochem. 83, 346.

Miseta A. and Csutora P. (2000). Relationship between the occurrence of cysteine in proteins and the complexity of organisms. Molecular Biology and Evolution, 17: 1232-1239.

Moretto G. and João de Mello Jr.L.S. (1999). Varroa jacobsoni infestation of adult Africanized and Italian honey bees (Apis mellifera) in mixed colonies in Brazil. Genetics and Molecular Biology, 22, 3: 321-323.

Mueller U.G. and Wolfenbarger L.L. (1999). AFLP genotyping and fingerprinting. Trends Ecol. Evol., 14: 389-394.

Nei M. and Tajima F. (1981). DNA polymorphism detectable by restriction endonucleases. Genetics, 97: 145-163.

Pejic I., Ajmone-Marsan P., Morgante M., Kozumplick V., Castiglioni P., Taramino G. and Motto M. (1998). Comparative analysis of genetic similarity among maize inbred lines detected by RFLPs, RAPDs, SSRs and
AFLPs. Theor. Appl. Genet., 97, 12481255.

Rand D. (2001). The units of selection on mitochondrial DNA. Annu. Rev. Ecol. Syst. 32: 415-448.

Rand D.M. and Kann L.M. (1996). Excess amino acid polymorphism in mitochondrial DNA; contrasts among genes from Drosophila, Mice, and Humans. Mol. Biol. Evol. 13(6): 735-748.

Rand D.M., Dorfsman M. and Kann L.M. (1994) . Neutral and non-neutral evolution of Drosophila mitochondrial DNA. Genetics, 138: 741-766.

Ruttner F. (1976). African races of honeybees, in: Proc. Int. Beekeeping Congr. 25, Apimondia, Bucharest, p. 1-20.

Ruttner F. (1988). Biogeography and Taxonomy of Honeybees, Springer Verlag, Heidelberg, New York.

Shah D.M. and Langley C.H. (1979). Inter and interspecific variation in restriction maps of Drosophila mtDNAs. Nature 281: 696-699.

Sheppard W.S., Rinderer T.E., Garnery L.. and Shimanuki, H. (1999). Analysis of Africanized honey bee mitochondrial DNA reveals further diversity of origin. Genet. Mol. Biol. 22: 1-10.

Sheppard W.S., Rinderer T.E., Meixner M.D., Yoo H.R., Stelzer. J.A., Schiff N.M., Kamel, S.M. and Krell, R. (1996). Hinf1 variation in mitochondrial DNA of old world honey bee subspecies. J. of Heredity 87: 35-40.

Vos P., Hogers R., Bleeker M., Reijans M., Vandelee T., Hornes M., Frijters A., Pot J., Peleman J., Kuiper M. and Zabeau M. (1995). AFLP: A new technique for DNA fingerprinting. Nucleic Acids Res., 23: 4407-4414.

William J., Ballard O. and Kreitman M. (1994). Unraveling selection in the mitochondrial genome of Drosophila. Genetics, 138: $757-$ 772.

Williams J.G.K., Kubelik A.R., Livak K.J., Rafalski J.A. and Tingey S.V. (1990). DNA polymorphisms amplified by arbitrary primers are useful as genetic markers. Nucleic Acids Res., 18: 6531-6535. 


\section{دراسات كيمو حيويه والبصمه الوراثيه ل د ن ا الميتوكوندريا في نحل العل فى المملكة العربية السعودية}

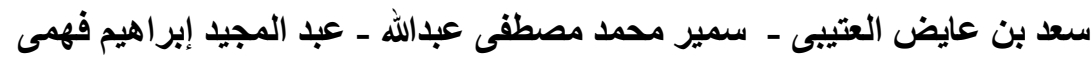

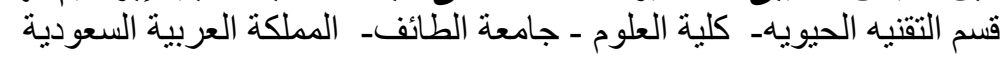

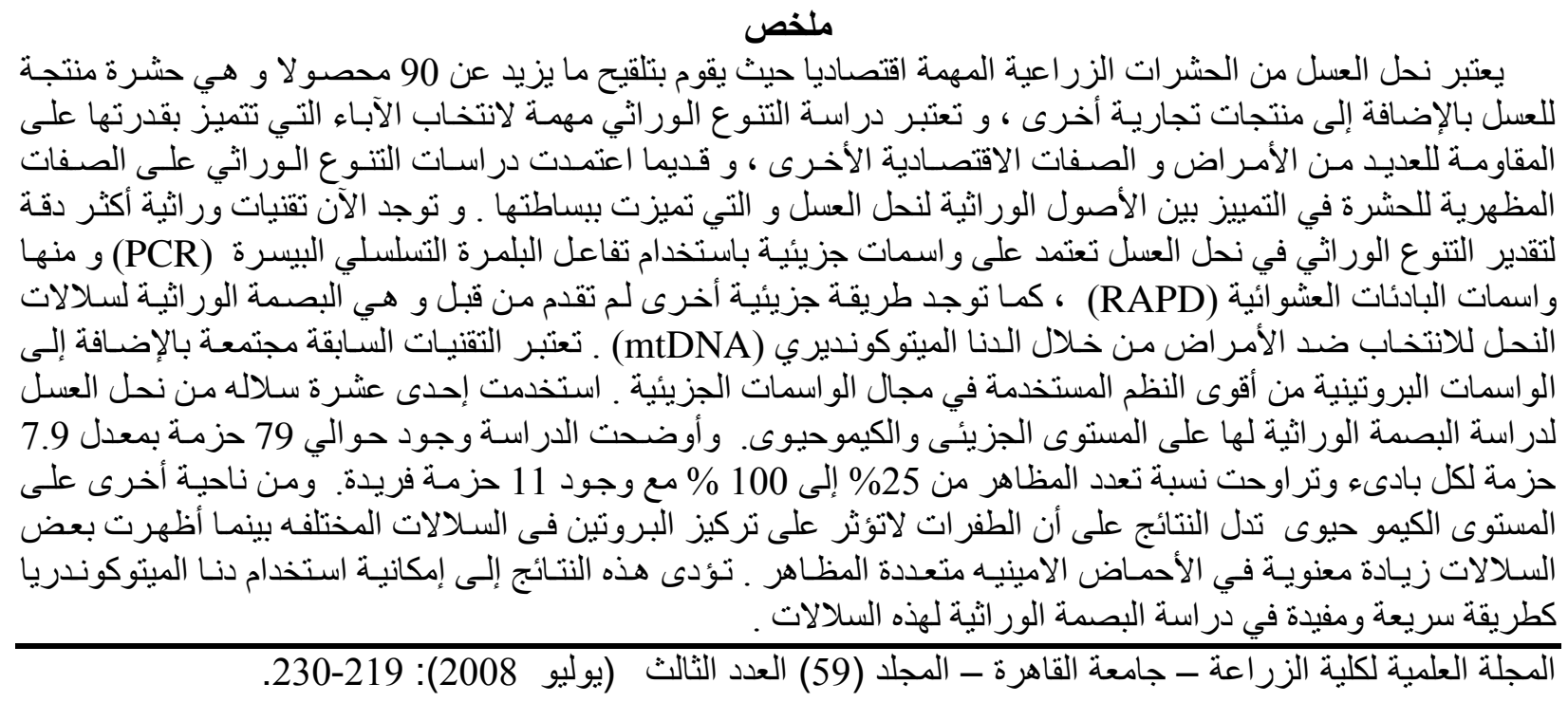

